\title{
UDC 621.384.65
}

\section{HIGH FLUX ACCELERATOR-BASED NEUTRON SOURCE}

\author{
T.A. Bykov ${ }^{1,2}$, A.A. Ivanov ${ }^{1}$, D.A. Kasatov ${ }^{1,2}$, Ia.A. Kolesnikov ${ }^{1,2}$, A.M. Koshkarev ${ }^{1,2}$, G.M. Ostreinov ${ }^{1,2}$, \\ A.N. Makarov ${ }^{1,2}$, I.M. Shchudlo ${ }^{1,2}$, E.O. Sokolova ${ }^{1,2}$, S.Yu. Taskaev ${ }^{1,2}$
}

\author{
${ }^{I}$ Budker Institute of Nuclear Physics, Novosibirsk, Russia \\ ${ }^{2}$ Novosibirsk State University, Novosibirsk, Russia
}

High-flux neutron sources are relevant to testing materials for thermonuclear facilities and hadron colliders, treating malignant tumors with boron neutron capture therapy, and other applications. An accelerator-based neutron source was proposed and implemented at the Budker Institute of Nuclear Physics in Novosibirsk, Russia. It comprises an originally designed tandem accelerator, a solid lithium target, and a neutron beam shaping assembly. The neutron source has been found capable of producing high neutron fluxes in different energy ranges, from thermal to fast. It is applicable to a wide range of research tasks, including the characterization of neutron detectors, intended for fusion studies, in-depth investigation of the promising ${ }^{11} \mathrm{~B}(p, \alpha) \alpha \alpha$ neutronless fusion reaction, etc.

Key words: neutron source, charge particle accelerator, lithium target.

DOI: $10.21517 / 0202-3822-2021-44-2-145-147$

\section{ИСТОЧНИК БОЛЬШИХ ПОТОКОВ НЕЙТРОНОВ НА ОСНОВЕ УСКОРИТЕЛЯ}

\author{
Т.А. Быков ${ }^{1,2}$, А.А. Иванов ${ }^{1}$, Д.А. Касатов ${ }^{1,2}$, Я.А. Колесников ${ }^{1,2}$, А.М. Кочкарёв ${ }^{1,2}$, Г.М. Остреинов, ${ }^{1,2}$ \\ А.Н. Макаров ${ }^{1,2}$, И.М. Щудло ${ }^{1,2}$, Е.О. Соколова ${ }^{1,2}$, С.Ю. Таскаев ${ }^{1,2}$
}

\author{
${ }^{1}$ Институт ядерной физики им. Г.И. Будкера СО РАН, Новосибирск, Россия \\ ${ }^{2}$ Новосибирский государственный университет, Новосибирск, Россия
}

Источники больших потоков нейтронов могут найти применение при исследовании материалов для термоядерных установок и адронных коллайдеров, лечении злокачественных опухолей методом бор-нейтронозахватной терапии и для других целей. В новосибирском Институте ядерной физики им. Г.И. Будкера был изобретён и изготовлен такой нейтронный источник на основе ускорителя, включающий впервые разработанный тандемный ускоритель оригинальной конструкции, твёрдую литиевую мишень и систему формирования пучка нейтронов. Было обнаружено, что разработанный нейтронный источник способен генерировать большие потоки нейтронов в различных диапазонах энергии - от тепловых нейтронов до быстрых. Он может применяться для многих целей, включая определение характеристик нейтронных детекторов, используемых в термоядерных исследованиях, а также при углублённом изучении перспективной безнейтронной термоядерной реакции ${ }^{11} \mathrm{~B}(p, \alpha) \alpha \alpha$.

Ключевые слова: нейтронный источник, ускоритель заряженных частиц, литиевая мишень.

\section{INTRODUCTION}

A neutron source based on a charged particle accelerator and a lithium target has been proposed and developed for boron neutron capture therapy (BNCT) $[1,2]$ at the Budker Institute of Nuclear Physics (BINP) in Novosibirsk, Russia. This paper describes the said neutron source and summarizes relevant research. The neutron source applicability for the testing of fusion materials is discussed.

\section{NEUTRON SOURCE}

The BINP neutron source comprises a DC vacuum insulation tandem accelerator (VITA), a lithium target, and a neutron beam shaping assembly. A schematic diagram of the neutron source is shown in Fig. 1. The VITA is used to provide a high-current proton/deuteron beam of up to $2.3 \mathrm{MeV}$. Negative ions injected into the VITA are accelerated by applying a positive potential to the central electrode, then stripped to positive ions, and accelerated again by the same potential. The VITA has a special design that does not include accelerating tubes [3] present in conventional tandem accelerators. Instead, it fea-

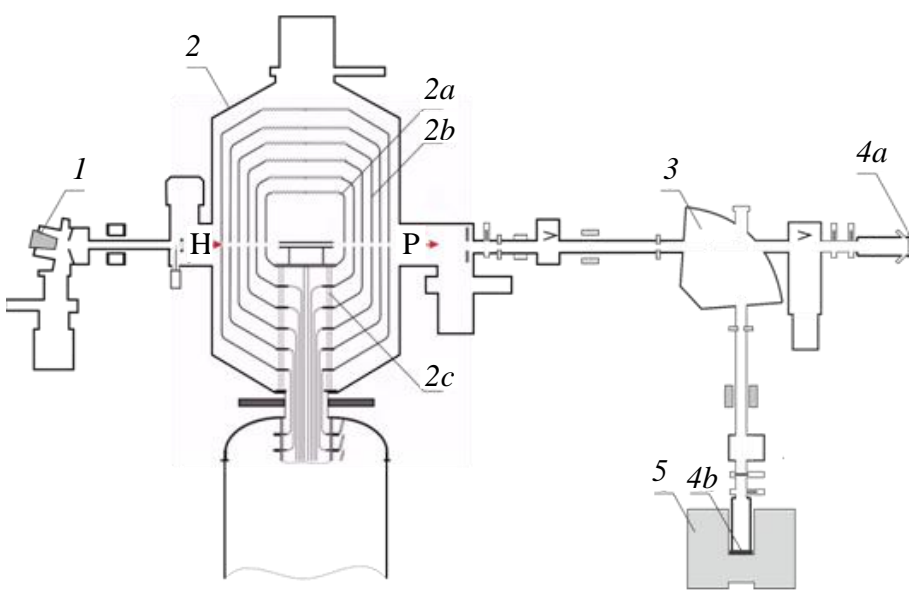

A cross-sectional view of the neutron source: 1 - negative ion source; 2 - vacuum insulated tandem accelerator $(2 a$ - high voltage electrode; $2 b$ - intermediate electrodes; $2 c$ - feedthrough insulator); 3 - bending magnet; 4 - lithium targets ( $4 a$ - horizontally; $4 b-$ vertically); 5 neutron beam shaping assembly 
tures intermediate nested electrodes $(2 b)$, fastened to a feedthrough insulator $(2 c)$, as shown in Figure. The advantage of this setup is that the ceramic parts of the feedthrough insulator are distanced well away from the ion beam, increasing the high-voltage strength of accelerating gaps given high ion beam current.

After acceleration, the ion beam is directed to the lithium target placed either horizontally $(4 a)$ or vertically $(4 b)$ behind the bending magnet. The low and high energy beam lines are equipped with diagnostics, such as retractable Faraday cups, beam current monitors, video cameras, beam profile scanner, stripping target efficiency monitor, and thermocouples installed on the beam apertures along its path. The lithium target (4) on a copper substrate is used to generate a neutron flux via the ${ }^{7} \mathrm{Li}(p, n)^{7} \mathrm{Be}$ - or ${ }^{7} \mathrm{Li}(d, n)$-reactions. The target assembly is water cooled [4].

\section{RESULTS AND DISCUSSION}

Proton beam energy varies in the range of $0.6-2.3 \mathrm{MeV}$ with a high-energy stability of $0.1 \%$. The beam current also varies in a wide range (from 0.5 to $10 \mathrm{~mA}$ ) with a high current stability $(0.4 \%)$ [5]. The VITA can generate a deuteron beam with similar characteristics.

A $2 \mathrm{MeV}$ proton beam was used for an in situ observation of blisters growth in copper and tantalum [6]. The neutron yield behavior generated the ${ }^{7} \mathrm{Li}(p, n)^{7} \mathrm{Be}$-reaction was determined as a function of neutron fluence to identify the copper substrate's potential blistering effect on the efficiency of neutron production.

Table shows the yields and energies of reaction products generated by the device.

The yields and energies of reaction products generated by the device

\begin{tabular}{|c|c|c|c|c|c|c|}
\hline Reaction & $\begin{array}{c}\text { Incident ion } \\
\text { energy, } \mathrm{MeV}\end{array}$ & $\begin{array}{c}\text { Product of } \\
\text { reaction }\end{array}$ & $\begin{array}{c}\text { Yield, } 10^{11} \\
\mathrm{mC}^{-1}\end{array}$ & $\begin{array}{c}\text { Mean ener- } \\
\text { gy, keV }\end{array}$ & $\begin{array}{c}\text { Maximum } \\
\text { energy, keV }\end{array}$ & Ref. \\
\hline${ }^{7} \mathrm{Li}(p, n){ }^{7} \mathrm{Be}$ & $\begin{array}{l}2.0 \\
2.1 \\
2.2 \\
2.3\end{array}$ & Neutrons & $\begin{array}{c}1.1 \\
2.13 \\
3.62 \\
5.78\end{array}$ & $\begin{array}{c}75 \\
110 \\
160 \\
230\end{array}$ & $\begin{array}{l}230 \\
350 \\
460 \\
570\end{array}$ & [7] \\
\hline $\begin{array}{c}{ }^{7} \mathrm{Li}(d, n){ }^{8} \mathrm{Be} ;{ }^{7} \mathrm{Li}(d, n) 2{ }^{4} \mathrm{He} \\
{ }^{7} \mathrm{Li}\left(p, p^{\prime} \gamma\right){ }^{7} \mathrm{Li}\end{array}$ & $\begin{array}{c}2.1 \\
1.85\end{array}$ & Photons & $\begin{array}{l}15 \\
0.9\end{array}$ & 5600 & $78 \quad 15000$ & $\begin{array}{l}{[8]} \\
{[9]}\end{array}$ \\
\hline
\end{tabular}

In the device, the neutron flux is generated by the ${ }^{7} \mathrm{Li}(p, n)^{7} \mathrm{Be}$ threshold reaction. A beam shaping assembly with a magnesium fluoride moderator is applied to convert this flux into a beam of epithermal neutrons with characteristics suitable for clinical testing of BNCT [10].

The device is capable of producing a beam of thermal neutrons with a plexiglas moderator. This beam is employed to irradiate cell cultures and laboratory animals for the boron neutron capture therapy (BNCT) development purposes $[11,12]$. It is also used to measure hazardous impurities in boron carbide ceramics and 316L-IG austenitic stainless steel considered for ITER [13].

A beam of monoenergetic neutrons with energies from 10 to $100 \mathrm{keV}$ is produced by kinematic collimation using several-micron-thick lithium foil targets. This beam is suitable for calibrating a dark matter detector [14] and is to be used for boron imaging by prompt gamma-ray spectroscopy.

Fast neutron flux is obtained via the ${ }^{7} \mathrm{Li}(d, n)$-reaction [8]. It is employed to study the activation of $\mathrm{B}_{4} \mathrm{C}$ ceramics and SS 316L ITER-grade steel by fast neutrons [15]. It is also intended for the radiation tests of fibers used in the laser calorimeter calibration system of the CMS electromagnetic detector developed for the High-Luminosity Large Hadron Collider at CERN.

A $478 \mathrm{keV}$-photon flux is produced by the ${ }^{7} \mathrm{Li}\left(p, p^{\prime} \gamma\right)^{7} \mathrm{Li}$-reaction (inelastic proton scattering by a lithium atomic nucleus) at a proton beam energy below $1.882 \mathrm{MeV}$, the threshold value for the ${ }^{7} \mathrm{Li}(p, n)^{7} \mathrm{Be}$-reaction. This beam is used for in situ measuring of the lithium layer thickness [16] and for determining the doses of high-LET radiation [17].

To sum it up, the device is applicable to a wide range of research tasks, including the characterization of neutron detectors designed for fusion studies, in-depth investigation of the promising ${ }^{11} \mathrm{~B}(p, \alpha) \alpha \alpha$ neutronless fusion reaction, etc.

\section{CONCLUSION}

The accelerator-based neutron source can produce high neutron fluxes in different energy ranges, from thermal to fast, that can be useful in various fields of research, including thermonuclear fusion. The research team has already been involved in neutron activation experiments conducted under the ITER project.

The study was supported by a grant (project № 19-72-30005) from the Russian Science Foundation. 


\section{REFERENCES}

1. Neutron Capture Therapy. Principles and Applications. Eds. W. Sauerwein, A. Wittig, R. Moss, Y. Nakagawa. - New York: Springer, 2012; doi: 10.1007/978-3-642-31334-9.

2. Dymova M., Taskaev S., Richter V., Kuligina E. Boron neutron capture therapy: current status and future perspectives. - Cancer Communications, 2020, vol. 40, p. 406-421; doi: 10.1002/cac2.12089.

3. Bayanov B., Belov V., Bender E., Bokhovko M., Dimov G., Kononov V., Kononov O., Kuksanov N., Palchikov V., Pivovarov V., Salimov R., Silvestrov G., Skrinsky A., Taskaev S. Accelerator based neutron source for the neutron-capture and fast neutron therapy at hospital. — Nucl. Instrum. and Methods A, 1998, vol. 413, p. 397-426; doi: 10.1016/S0168 9002(98)00425-2.

4. Bayanov B., Belov V., Kindyuk V., Oparin E., Taskaev S. Lithium neutron producing target for BINP accelerator-based neutron source. - Applied Radiation and Isotopes, 2004, vol. 61, p. 817—821; doi: 10.1016/j.apradiso.2004.05.032.

5. Taskaev S. Accelerator based epithermal neutron source. - Phys. Part. Nuclei, 2015, vol. 46, p. 956-990; doi: $10.1134 / \mathrm{S} 1063779615060064$.

6. Badrutdinov A., Bykov T., Gromilov S., Higashi Y., Kasatov D., Kolesnikov I., Koshkarev A., Makarov A., Miyazawa T., Shchudlo I., Sokolova E., Sugawara H., Taskaev S. In situ observations of blistering of a metal irradiated with 2-MeV protons. Metals, 2017, vol. 7, 558; doi: 10.3390/met7120558.

7. Lee C.L., Zhou X.-L. Thick target neutron yields for the ${ }^{7} \mathrm{Li}(p, n)^{7} \mathrm{Be}$ reaction near threshold. — Nucl. Instrum. and Methods in Phys. Res. Sect. B, 1999, vol. 152, p. 1-11; doi: 10.1016/S0168-583X(99)00026-9.

8. Kasatov D., Koshkarev A., Makarov A., Ostreinov G., Taskaev S., Shchudlo I. Fast-neutron source based on a vacuum-insulated tandem accelerator and a lithium target. - Instruments and Experimental Techniques, 2020, vol. 63, p. 611-615; doi: 10.1134/S0020441220050152.

9. Bykov T., Kasatov D., Kolesnikov Ia., Koshkarev A., Makarov A., Shchudlo I., Sokolova E., Taskaev S. Measurement of the ${ }^{7} \mathrm{Li}\left(p, p^{\prime} \gamma\right)^{7} \mathrm{Li}$ reaction cross-section and $478 \mathrm{keV}$ photon yield from a thick lithium target at proton energies from 0.7 to 1.85 MeV. - Applied Radiation and Isotopes, 2021, vol. 175, 109821; doi: 10.1016/j.apradiso.2021.109821.

10. Zaidi L., Belgaid M., Taskaev S., Khelifi R. Beam shaping assembly design of ${ }^{7} \operatorname{Li}(p, n)^{7} \mathrm{Be}$ neutron source for boron neutron capture therapy of deep-seated tumor. - Applied Radiation and Isotopes, 2018, vol. 139, p. 316-324; doi: 10.1016/j.apradiso.2018.05.029

11. Sato E., Zaboronok A., Yamamoto T., Nakai K., Taskaev S., Volkova O., Mechetina L., Taranin A., Kanygin V., Isobe T., Mathis B., Matsumura A. Radiobiological response of U251MG, CHO-K1 and V79 cell lines to accelerator-based boron neutron capture therapy. — J. Radiat. Res., 2018, vol. 59, p. 101-107; doi: 10.1093/jrr/rrx071.

12. Zavjalov E., Zaboronok A., Kanygin V., Kasatova A., Kichigin A., Mukhamadiyarov R., Razumov I., Sycheva T., Mathis B., Maezono S., Matsumura A., Taskaev S. Accelerator-based boron neutron capture therapy for malignant glioma: a pilot neutron irradiation study using boron phenylalanine, sodium borocaptate and liposomal borocaptate with a heterotopic U87 glioblastoma model in SCID mice. - Intern. J. Radiat. Biology, 2020, vol. 96, p. 868 - 878; doi: 10.1080/09553002.2020.1761039.

13. Shoshin A., Burdakov A., Ivantsivskiy M., Polosatkin S., Klimenko M., Semenov A., Taskaev S., Kasatov D., Shchudlo I., Makarov A., Davydov N. Qualification of boron carbide ceramics for use in ITER ports. - IEEE Trans. on Plasma Science, 2020, vol. 48, p. 1474-1478; doi: 10.1109/TPS.2019.2937605.

14. Makarov A., Taskaev S. Beam of monoenergetic neutrons for the calibration of a dark-matter detector. — JETP Letters, 2013, vol. 97, p. 667-669; doi: 10.1134/S0021364013120072.

15. Shoshin A., Burdakov A., Ivantsivskiy M., Polosatkin S., Klimenko M., Semenov A., Sulyaev Yu., Zaitsev E., Polozova P., Taskaev S., Kasatov D., Shchudlo I., Bikchurina M. Test results of boron carbide ceramics for ITER port protection. - Fusion Engineering and Design, 2021, vol. 169, 112426; doi: 10.1016/j.fusengdes.2021.112426.

16. Kasatov D., Kolesnikov Ia., Koshkarev A., Makarov A., Sokolova E., Shchudlo I., Taskaev S. Method for in situ measuring the thickness of a lithium layer. - JINST, 2020, vol. 5, P10006; doi: 10.1088/1748-0221/15/10/P10006.

17. Dymova M., Dmitrieva M., Kuligina E., Richter V., Savinov S., Shchudlo I., Sycheva T., Taskaeva I., Taskaev S. Method of measuring high-LET particles dose. — Radiation Research, 2021, vol. 196; doi: 10.1667/RADE-21-00015.1.

Budker Institute of Nuclear Physics, 11 Lavrentiev ave., 630090, Novosibirsk, Russia; Novosibirsk State University, 1 Pirogov str., 630090, Novosibirsk, Russia

T.A. Bykov, graduate student; timaisabrony@gmail.com

A.A. Ivanov, PhD, Prof., Head of Laboratory; Budker Institute of Nuclear Physics, A.A.Ivanov@inp.nsk.su

D.A. Kasatov, PhD, researcher; kasatovd@gmail.com

Ia.A. Kolesnikov, graduate student; katyono@mail.ru

A.M. Koshkarev, engineer; kent_brockman4@mail.ru

G.M. Ostreinov, junior researcher; wtfsnoo@gmail.com

A.N. Makarov, PhD, senior researcher; alexxmak314@gmail.com

I.M. Shchudlo, researcher; cshudlo.i.m@gmail.com

E.O. Sokolova, graduate student; buiya@bk.ru

S.Yu. Taskaev, PhD, chief researcher; taskaev@inp.nsk.su 